\title{
FORMULATION OF SERUM GEL CONTAINING ANGELICA KEISKEI LEAF EXTRACT AS AN ANTIOXIDANT AND TYROSINASE ENZYME INHIBITOR
}

\author{
DIAH LIA AULIFA ${ }^{1}{ }^{*}$, RIZKA Y. NOERFITRI ${ }^{1}$, DEBY TRISTIYANTI ${ }^{2}$, ARIF BUDIMAN ${ }^{3}$
}

${ }^{1}$ Department of Pharmaceutical Biology, Indonesian School of Pharmacy, JI Soekarno Hatta no.354, Bandung, Indonesia, ${ }^{2}$ Department of Pharmaceutical Technology, Indonesian School of Pharmacy, JI Soekarno Hatta no.354, Bandung, Indonesia, ${ }^{3}$ Department of Pharmaceutics and Pharmaceutical Technology, Faculty of Pharmacy Universitas Padjadjaran, Indonesia Email: diahliaaulifa@stfi.ac.id

Received: 01 Mar 2020, Revised and Accepted: 02 Apr 2020

\section{ABSTRACT}

Objective: The aim of this study was to formulate and evaluate the efficacy of Angelica keiskei (AK) leaf extract in serum gel as an antioxidant and tyrosinase enzyme inhibitor.

Methods: The leaves of AK were extracted using the maceration method, while the antioxidant and tyrosinase enzyme inhibitory activities were determined using 1,1-diphenyl-2-picrylhydrazyl (DPPH) and L-Tyrosine as assay and substrate, respectively. Subsequently, the extract was formulated into serum gel and evaluated for physical stability, antioxidant and inhibitory activity to tyrosinase enzyme.

Results: The results showed that AK leaf extract has antioxidant activity, with an $\mathrm{IC}_{50}$ value $=7.73 \mu \mathrm{g} / \mathrm{ml}$, while the tyrosinase enzyme inhibitory power had an $\mathrm{IC}_{50}$ value $=500 \mu \mathrm{g} / \mathrm{ml}$. Based on physical stability, the serum gel was stable after $28 \mathrm{~d}$ of storage. The serum gel of AK leaf extract also showed antioxidant activity and tyrosinase enzyme inhibition with $\mathrm{IC}_{50}$ value of $16.68 \mu \mathrm{g} / \mathrm{ml}$ and $741.62 \mu \mathrm{g} / \mathrm{ml}$, respectively.

Conclusion: This study demonstrated that the serum gel of AK leaf extract has potential as a skin lightening agent and is safe for use as a topical preparation.

Keywords: Angelica keiskei extract, Serum gel, Antioxidant, Tyrosinase enzyme inhibitor

(C) 2020 The Authors. Published by Innovare Academic Sciences Pvt Ltd. This is an open access article under the CC BY license (http://creativecommons.org/licenses/by/4.0/) DOI: http://dx.doi.org/10.22159/ijap.2020v12i3.37303. Journal homepage: https://innovareacademics.in/journals/index.php/ijap

\section{INTRODUCTION}

Generally, the skin as an organ protects the body from harmful effects and damage from the external environment, such as ultraviolet (UV) rays since their effect causes faster skin aging and sunburn [1, 2]. However, the use of Angelica keiskei (AK) leaf extracts as antioxidants and photoprotection help in preventing the effects of UV rays. This leaf contains a pigment known as melanin, which acts as a defence mechanism against harmful factors [3]. It also affects abnormal pigmentation and melanoma, such as hyperpigmentation. Also, the overproduction and accumulation of this pigment could be a serious aesthetic problem of the skin resulting in melasma or age spots. To synthesize this substance, the body requires tyrosinase enzyme to mediate the conversion of tyrosine to dihydroxyphenylalanine (DOPA), which converts to dopaquinone and eventually melanin. Inhibiting tyrosinase enzyme activity becomes an important step to controlling its biosynthesis, which helps in preventing hyperpigmentation disorders $[4,5]$.

In addition, there are various topical products used as antioxidants and tyrosinase enzyme inhibitor, which are either from natural sources or synthesized. Some of these are prepared during cosmetic production, and the use of the synthetic types in high doses causes harmful side effects $[1,2,4]$. However, AK occurs naturally and could serve as an alternative to these synthetic products.

This $A K$ is a native plant from Japan. The dark green leaves of this plant have been recognized as a medicinally important herb in Asia. Previous studies have shown that the ethanol extract of $\mathrm{AK}$ is an excellent antioxidant, which also inhibits melanin production with low cytotoxic effects $[1,6]$. One of the group of compounds contained in AK which have many biological activities including being an antioxidant and a melanin inhibitor are chalcones. Also, these two activities are attributed to the two aromatic rings with an unsaturated chain contained in these compounds [7].

Furthermore, the serum gel is the popular topical dosage form used to enhance the quality of the skin because it acts as a moisturizer, thereby enhancing the effects of these compounds in the epithelium [8].
Therefore, a serum gel of AK leaf extract was prepared and evaluated for antioxidant and tyrosinase enzyme inhibitory activities.

\section{MATERIALS AND METHODS}

Materials

\section{Plant material}

The leaf of AK was collected from Lombok, West Nusa Tenggara and was authenticated by School of Life Sciences and Technology, Bandung Institute of Technology (ITB) No. 401/I1. C02.2/PL/2019.

Chemicals

The tyrosinase enzyme, L-Tyrosine, 1,1-diphenyl-2-picrylhydrazyl (DPPH), Gallic acid, Quercetin and Vitamin C were purchased from Sigma Aldrich. All other chemicals were of pharmaceutical and technical grades.

\section{Methods}

\section{Preparation of plant extracts}

The leaves of AK were dried at room temperature and ground in a mortar. Two hundred g of AK leaves powder were extracted in 2000 $\mathrm{ml} 96 \%$ ethanol using maceration method for three $\times 24 \mathrm{~h}$ at room temperature. The ethanol was removed by a rotary evaporator, IKA Company, Germany (IKA RV 10) at $40-50{ }^{\circ} \mathrm{C}$ to obtain the crude extract [9].

\section{Phytochemical screening extract}

Phytochemical screening was carried out to determine the presence of secondary metabolites in AK leaf extract, including alkaloids, flavonoids, tannins, polyphenols, quinones, steroids/triterpenoids, saponins, monoterpenes and sesquiterpenes [9].

\section{Total phenols determination}

$0.5 \mathrm{ml} \mathrm{AK}$ leaf extract was dissolved in methanol (770 PPM) and mixed with aqueous $\mathrm{Na}_{2} \mathrm{CO}_{3}(4 \mathrm{ml}, 1 \mathrm{M})$ and Folin Ciocalteu reagent 
( $5 \mathrm{ml}, 1: 10$ in distilled water), the mixture was then incubated for 15 $\mathrm{min}$. The total phenols were evaluated by UV/visible rays at $755 \mathrm{~nm}$. The curve of the standard was prepared using gallic acid solutions with various concentrations. The values of total phenol were expressed in terms of gallic acid equivalent as the reference compound [10].

\section{Total flavonoids determination}

$0.5 \mathrm{ml} \mathrm{AK}$ leaf extracts $(500 \mathrm{mg} / \mathrm{ml})$ in methanol were mixed with $1.5 \mathrm{ml}$ of methanol, $0.1 \mathrm{ml}$ of $1 \mathrm{M}$ potassium acetate, $0.1 \mathrm{ml}$ of $10 \%$ aluminium chloride and $2.8 \mathrm{ml}$ of distilled water. This was then incubated for $15 \mathrm{~min}$. The absorbance of the mixture was measured at $410 \mathrm{~nm}$. The curve of the standard was prepared using quercetin solutions with various concentrations in methanol. Total flavonoids values were expressed in terms of quercetin equivalent, as the reference compound [11].

\section{Antioxidant activity test of AK leaf extract}

The solution of DPPH (50 ppm) was prepared using methanol as a solvent. The sample solution and DPPH (1:1) were mixed and the mixed operating time was determined. The sample solution was prepared with various concentrations and mixed with the solution of DPPH (1: 1), stored during an operating time and then measured for absorbance at $\lambda_{\max }$. The absorbance value was calculated for the value of $\%$ inhibition by the following equation:

$$
\% \text { Inhibition }=[1-(\text { A sample } / \text { A DPPH })] \times 100
$$

Where, \% Inhibition is the percentage capacity of the free radical inhibition, Asample is absorbance of the sample at $515 \mathrm{~nm}$, and ADppH is the absorbance of DPPH solution at $515 \mathrm{~nm}$. Linear regression curve between $\%$ inhibition and sample concentration were made, the linear equation and $\mathrm{IC}_{50}$ were obtained [2].

\section{In vitro testing of tyrosinase enzyme inhibitory activity}

Extracts were dissolved in phosphate buffer (pH 6.5) containing $1 \%$ of dimethyl sulfoxide (DMSO) to obtain solution concentrations of $500 \mu \mathrm{g} / \mathrm{ml}$. A total of $70 \mu \mathrm{l}$ of the extract solution of each dilution was added to $30 \mu \mathrm{l}$ of the enzyme tyrosinase (Sigma, $333 \mathrm{units} / \mathrm{ml}$ in phosphate buffer). Plates were incubated for $5 \mathrm{~min}$ at room temperature, to which were added $110 \mu \mathrm{l}$ of substrate $1 \mathrm{mmol} \mathrm{L-}$ tyrosine and incubated for $30 \mathrm{~min}$ at room temperature. The solution in each well was measured using a microwell plate reader at a wavelength of $492 \mathrm{~nm}$ to determine the percent inhibition and the value of $50 \%$ inhibitory concentration $\left(\mathrm{IC}_{50}\right)$. The percentage of tyrosinase activity inhibition was calculated as inhibition $\%=$ $[(\mathrm{A}-\mathrm{B}) / \mathrm{A}] \times 100$, where $A$ is the absorbance of the control at 492 $\mathrm{nm}$ and $B$ is the absorbance of the samples at $492 \mathrm{~nm}$. Kojic acid was used as a positive control [5].

\section{Formulation of serum gel from AK leaf extract}

The serum gel consisting of AK leaf extract and all other ingredients were prepared according to the formula presented in table 1. Hydroxyethylcellulose (HEC) was dispersed into distilled water $\left(50^{\circ} \mathrm{C}\right)$ with constant stirring using a mechanical stirrer. The Extract and all ingredients were dissolved in distilled water before adding to the HEC solution. The mixtures were stirred until homogeneity was achieved. The physical stability of serum gel containing AK leaf extract was evaluated for organoleptic property, homogeneity, $\mathrm{pH}$, viscosity, and spreadability, after $28 \mathrm{~d}$ of storage [12].

Table 1: Formulation of serum gel containing AK leaf extract

\begin{tabular}{ll}
\hline Ingredients & Composition of serum gel (\%) \\
\hline AK leaf extract & 0.5 \\
HEC & 0.5 \\
Propylene glycol & 10 \\
DMSO & 2 \\
Methylparaben & 0.3 \\
Distilled water added & 100 \\
\hline
\end{tabular}

\section{Statistical analysis}

The data of the experiment were analyzed by the one-way analysis of variance (ANOVA) at the level of $(\mathrm{P}<0.05)$ and all data results were measured as a mean of samples \pm standard deviation (SD).

\section{RESULTS AND DISCUSSION}

The results obtained at School of Life Sciences and Technology, Bandung Institute of Technology (ITB) demonstrated Angelica keiskei as the specie used in this study. $96 \%$ ethanol was used as a solvent due to it's universal dissolution characteristics for both polar and nonpolar compounds, producing a percent recovery of $21.83 \%$ [13]. In the extraction process, maceration method was used to protect compounds contained in AK leaf, which are responsible for the inhibition of tyrosinase enzyme and for the antioxidant activity [4].

The phytochemical screening was carried out to evaluate the presence of secondary metabolites in the AK leaf extract. Alkaloids, flavonoids, polyphenols, quinones, tannins, steroids and triterpenoids were detected. This result supports the assumption that tyrosinase enzyme inhibitory compounds and antioxidant compounds exist in AK leaf extracts, as flavonoids and phenols $[14,15]$.

Flavonoids have been recognized as an antioxidant agent and their effects are considerable on human nutrition and health. Flavonoids are known to exert their action by a scavenging or chelating process. Phenolic compounds also are antioxidant agents that act as free radical terminators [16]. The total contents of flavonoids from $\mathrm{AK}$ leaf extract in terms of quercetin equivalent was $3.532 \mathrm{~g} \mathrm{QE} / 100 \mathrm{~g}$, while the phenol contents of AK leaf in terms of gallic acid equivalent was $2.367 \mathrm{~g} \mathrm{GAE} / 100 \mathrm{~g}$. According to our study, the high contents of flavonoids and phenol in AK leaf extract is responsible for its high radical scavenging activity [10]. This result further confirms that AK leaf extract has potential activity as a tyrosinase enzyme inhibitor.

DPPH method is one of the common methods used to determine the antioxidant activity for preliminary testing of extracts [2]. The result of antioxidant activity can be seen in table 2 .

Table 2: The result of antioxidant activity from AK leaf extract

\begin{tabular}{ll}
\hline Sample & IC $_{50}(\boldsymbol{\mu g} / \mathbf{m l})$ \\
\hline AK leaf extract & 7.73 \\
Kojic Acid & 3.97 \\
\hline
\end{tabular}

The antioxidant transfers the hydrogen content to DPPH, which is a free radical. When the free radicals are scavenged by antioxidants, the color of DPPH will be changed from purple to yellow. The observed $\mathrm{IC}_{50}$ value showed that $\mathrm{AK}$ leaf extract exhibits strong antioxidant activity with $\mathrm{IC}_{50}$ value below 10 $\mu \mathrm{g} / \mathrm{ml}$. The $\mathrm{IC}_{50}$ of AK leaf extracts is almost similar with kojic acid as a standard substance with $\mathrm{IC}_{50}$ of $3.97 \mu \mathrm{g} / \mathrm{ml}$. The strong antioxidant activity of the extract could be attributed to its high levels of total flavonoids and polyphenols. Having $\mathrm{OH}$ at $\mathrm{C}$ $3, \mathrm{C}-4$ oxo, double bond at $\mathrm{C}-2$ and $\mathrm{C}-3$ and ortho di OH at C-3'C4', indicated that the flavonoids have very high antioxidant activity [17]. 
To determine the inhibitory activity of tyrosinase in the extract, the AK leaf extract were tested and compared with kojic acid as a control. The $\mathrm{IC}_{50}$ values were evaluated by the dose-response curves through serial dilution of the AK leaf extract and kojic acid at various concentrations. The inhibition of tyrosinase enzyme by AK leaf extract can be seen in table 3 .

Table 2: The results of tyrosinase enzyme inhibitory activity of AK leaf extract

\begin{tabular}{ll}
\hline Sample & IC $_{50}(\mu \mathrm{g} / \mathbf{m l})$ \\
\hline AK leaf extract & 500 \\
Kojic Acid & 573 \\
\hline
\end{tabular}

The results indicated that the ethanolic extract of AK leaf shows weak activity for tyrosinase enzyme inhibition. The previous article reported that the isoprenoid-substituted moiety contained in AK leaf extract can enhance the ability of flavonoids to inhibit melanin biosynthesis with less cytotoxicity [18]. The article also stated that xanthoangelol and 4-hydroxyderricin contained in AK leaf extract show tyrosinase enzyme inhibitory activity with IC50 values of $15.87 \pm 1.21 \mu \mathrm{M}$ and $60.14 \pm 2.29 \mu \mathrm{M}$, respectively [19]. Though the results in this study show weak activity, the extracts of AK leaf still have potential as tyrosinase inhibitors and the advantage of the low cytoxicity makes it safer for topical usage in humans.

The gel was prepared with AK leaf extract because of the advantages it profers. This includes being easy to use, having high water content and reduced contact time, all of which contribute to the reduction of the risk of inflammation. HEC is a polymer that has been used in the gel formulation due to its biosafety, efficacy, and stability [20]. Propylene glycol was used as a moisturizer and enhancer of gel, which could improve the solubility and diffusion of the active substance contained in AK through the skin [21]. Methylparaben was used as a preservative to prevent the gel damage caused by bacteria [22]. DMSO has been known as a permeation enhancer of hydrophilic and hydrophobic drugs. The properties of DMSO can make it an interesting excipient in topical dosage form due to its enhancement of drug permeability [23]. The serum gel formulation has a smooth texture that is homogeneous and characteristic of AK leaf extracts. The homogeneity of serum gel characteristics remained similar after $28 \mathrm{~d}$ of storage. The $\mathrm{pH}$ of serum gel containing AK leaf extract can be seen in the fig. 1 .

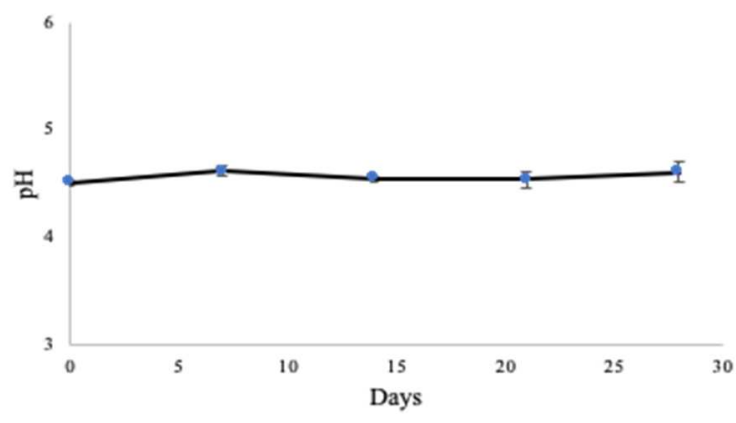

Fig. 1: pH of serum gel containing Angelica keiskei leaf extract (The data were calculated as mean $\pm S D ; n=3$ )

Fig. 1 indicates that the $\mathrm{pH}$ of serum gel containing AK leaf extract did not change significantly after $28 \mathrm{~d}$ storage and remained within the acceptable $\mathrm{pH}$ for topical preparations, which is between 4.5-6.5 [4].

The viscosity of the serum gel containing AK leaf extract can be seen in the fig. 2.

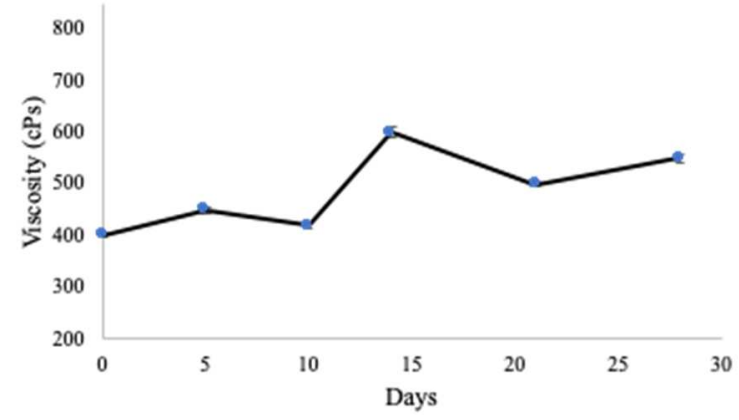

Fig. 2: Viscosity of serum gel containing AK leaf extract (The data were calculated as mean $\pm S D ; n=3$ )

Fig. 2 indicates that the viscosity of serum gel containing AK leaf extract did not change significantly after $28 \mathrm{~d}$ storage and remained within the acceptable viscosity for serum gel. The acceptable viscosity value of serum gel is in the range of 230-1150 cPs.

Spreadability is one parameter that can affect the efficacy of serum gel; hence, the evaluation of spreadability is important in topical dosage forms [24-26]. The Spreadability test result of serum gel containing AK leaf extract can be seen in the fig. 3 .

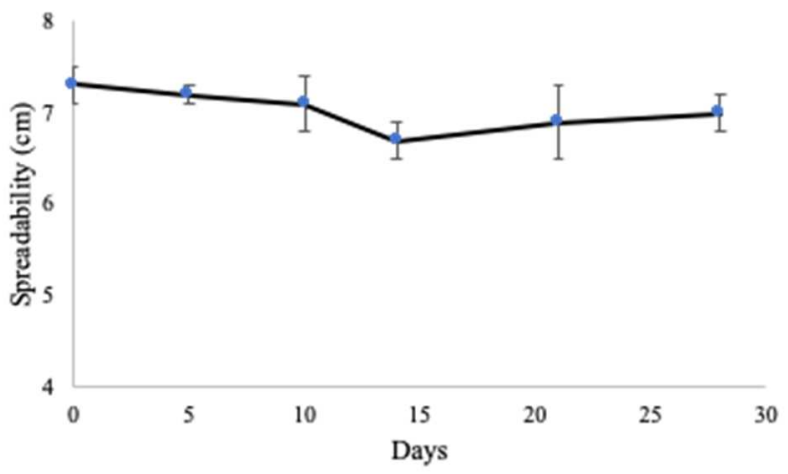

Fig. 3: The result of Spreadability of serum gel containing AK leaf extracts (The data were calculated as mean $\pm S D ; n=3$ )

Fig. 3 indicates that the spreadability of serum gel containing AK leaf extracts did not change significantly after $28 \mathrm{~d}$ storage and remained within the acceptable range of 5-7 cm [12, 27].

The result of tyrosinase enzyme inhibitory activity and antioxidant activity of serum gel containing AK leaf extract are shown in table 4 .

Table 4: The result of tyrosinase enzyme inhibitory activity and antioxidant activity of serum gel containing AK leaf extract

\begin{tabular}{lll}
\hline Sample & IC $_{\mathbf{5 0}}$ of tyrosinase enzyme inhibitory activity $(\boldsymbol{\mu g} / \mathbf{m l})$ & IC $_{\mathbf{5 0}}$ of antioxidant activity $(\boldsymbol{\mu g} / \mathbf{m l})$ \\
\hline Serum gel containing AK leaf extract & 741.62 & 16.68 \\
Serum gel containing Kojic Acid & 689.12 & 12.20 \\
\hline
\end{tabular}


The serum gel of AK leaf extract also showed antioxidant activity and tyrosinase enzyme inhibition with $\mathrm{IC}_{50}$ value $=16.68 \mu \mathrm{g} / \mathrm{ml}$ and $741.62 \mu \mathrm{g} / \mathrm{ml}$, respectively. This result is almost similar with that obtained with the serum gel of kojic acid as a positive control with an $\mathrm{IC}_{50}$ value $=12.20 \mu \mathrm{g} / \mathrm{ml}$ for antioxidant activity and $\mathrm{IC}_{50}$ value $=$ $689.12 \mu \mathrm{g} / \mathrm{ml}$ for tyrosinase enzyme inhibitory activity. This indicated that the serum gel containing AK leaf extract has high levels of total flavonoids and polyphenols, which have strong antioxidant activity and tyrosinase enzyme inhibitory activity [10].

\section{CONCLUSION}

In this research, the AK leaf extract was found to have antioxidant activity with an $\mathrm{IC}_{50}$ value $=7.73 \mu \mathrm{g} / \mathrm{ml}$, while the activity of AK leaf extract against the tyrosinase enzyme showed inhibition with an $\mathrm{IC}_{50}$ value $=500 \mu \mathrm{g} / \mathrm{ml}$. This result is almost similar with kojic acid as a positive control with an $\mathrm{IC}_{50}$ value $=3.97 \mu \mathrm{g} / \mathrm{ml}$ for antioxidant activity and $\mathrm{IC}_{50}$ value $=573 \mu \mathrm{g} / \mathrm{ml}$ for tyrosinase enzyme inhibitory activity. The serum gel of AK leaf extract also showed antioxidant activity and tyrosinase enzyme inhibition with $\mathrm{IC}_{50}$ value $=16.68$ $\mu \mathrm{g} / \mathrm{ml}$ and $741.62 \mu \mathrm{g} / \mathrm{ml}$, respectively. This indicated that serum gel containing AK leaf extract still has high levels of total flavonoids and polyphenols with strong antioxidant activity and tyrosinase enzyme inhibitory activity. Based on physical stability, the serum gel of AK leaf extract was stable after 28-day storage. It can be concluded that the serum gel of AK leaf extract has potential as a skin lightening preparation and is safe to be used as a topical preparation.

\section{FUNDING}

Nil

\section{AUTHORS CONTRIBUTIONS}

All the authors have contributed equally.

\section{CONFLICT OF INTERESTS}

None to declare

\section{REFERENCES}

1. Willis I, Kligman A, Epstein J. Effects of long ultraviolet rays on human skin: photoprotective or photoaugmentative? J Invest Dermatol 1972;59:416-20.

2. Budiman A, Praditasari A, Rahayu D, Aulifa DL. Formulation of antioxidant gel from black mulberry fruit extract (Morus nigra L.). J Pharm Bioallied Sci 2019;11:216-22.

3. Di Petrillo A, Gonzalez Paramas AM, Era B, Medda R, Pintus F, Santos Buelga C, et al. Tyrosinase inhibition and antioxidant properties of Asphodelus microcarpus extracts. BMC Complem Altern Med 2016;16:453.

4. Budiman A, Khaira N, Aulifa DL. Peel-off gel formulation from black mulberries (Morus Nigra L.) leaves extract as a tyrosinase inhibitor. Int J Drug Delivery Technol 2019;9:525-9.

5. Adhikari A, Devkota HP, Takano A, Masuda K, Nakane T, Basnet $\mathrm{P}$, et al. Screening of nepalese crude drugs traditionally used to treat hyperpigmentation: in vitro tyrosinase inhibition. Int J Cosmetic Sci 2008;30:353-60.

6. Li L, Aldini G, Carini M, Chen CYO, Chun HK, Cho SM, et al. Characterisation, extraction efficiency, stability and antioxidant activity of phytonutrients in Angelica keiskei. Food Chem 2009;115:227-32.

7. Nerya O, Musa R, Khatib S, Tamir S, Vaya J. Chalcones as potent tyrosinase inhibitors: the effect of hydroxyl positions and numbers. Phytochem 2004;65:1389-95.

8. Jyothi D, Koland M. Formulation and evaluation of an herbal anti-inflammatory gel containing Trigonella foenum greacum seed extract. Int J Pharm Pharm Sci 2016;8:41-4.
9. Budiman A, Rusnawan DW, Yuliana A. Antibacterial activity of Piper betle L. extract in cream dosage forms against Staphylococcus aureus and Propionibacterium acne. J Pharm Sci Res 2018;10:493-6.

10. Pourmorad SJ, Hosseinimehr, Shahabimajd N. Antioxidant activity, phenol and flavonoid contents of some selected iranian medical plants. Afr J Biotechnol 2006;5:1142-5.

11. Chang CC, Yang MH, Wen HM, Chern JC. Estimation of total flavonoid content in propolos by two complementary colorimetric methods. J Food Drug Anal 2003;10:178-82.

12. Budiman A, Aulifa DL, Kusuma ASW, Kurniawan IS, Sulastri A. Peel-off gel formulation from black mulberries (Morus nigra L.) extract as an anti-acne mask. Natl J Physiol Pharm Pharmacol 2017;7:1-8.

13. Shaalan EA, Canyon D, Younes MW, Abdel Wahab H, Mansour AH. A review of botanical phytochemicals with mosquitocidal potential. Environ Int 2005;31:1149-66.

14. de Freitas MM, Fontes PR, Souza PM, Fagg CW, Guerra EN, de Medeiros Nóbrega YK, et al. Extracts of Morus nigra L. leaves standardized in chlorogenic acid, rutin and isoquercitrin: tyrosinase inhibition and cytotoxicity. PloS One 2016;11:e0163130.

15. Jin Q, Yang J, Ma L, Cai J, Li J. Comparison of polyphenol profile and inhibitory activities against oxidation and $\alpha$-glucosidase in mulberry (genus Morus) cultivars from China. J Food Sci 2015;80:C2440-51.

16. Shahidi F, Wanasundara PKJPD. Phenolic antioxidants. Crit Rev Food Sci Nutr 1992;32:67-103.

17. Fidrianny I, Suhendy H, Insanu M. Correlation of phytochemical content with an antioxidant potential of various sweet potato (Ipomoea batatas) in West Java, Indonesia. Asian Pac J Trop Biomed 2018;8:25-30.

18. Arung ET, Furuta S, Sugamoto K, Shimizu K, Ishikawa H, Matsushita YI, et al. The inhibitory effects of representative chalcones contained in Angelica keiskei on melanin biosynthesis in B16 melanoma cells. Nat Prod Commun 2012;7:1007-10.

19. Lee JH, Mei HC, Kuo I, Lee TH, Chen YH, Lee CK. Characterizing tyrosinase modulators from the roots of Angelica keiskei using tyrosinase inhibition assay and UPLC-MS/MS as the combinatorial novel approach. Molecules 2019;24:3297.

20. Li L, Ben Y, Yuan S, Jiang S, Xu J, Zhang X. Efficacy, stability, and biosafety of sifuvirtide gel as a microbicide candidate against HIV-1. PloS One 2012;7:e37381.

21. Benson HA. Transdermal drug delivery: penetration enhancement techniques. Curr Drug Delivery 2005;2:23-33.

22. Patil PM, Wankhede SB, Chaudhari PD. Stability-indicating HPTLC method for simultaneous determination of Ketoprofen, methylparaben and propylparaben in gel formulation. J Pharm Res 2013;6:945-53.

23. Dey S, Mazumder B, Patel JR. Enhanced percutaneous permeability of acyclovir by DMSO from topical gel formulation. Int J Pharm Sci Drug Res 2009;1:13-8.

24. Shukr M, Metwally GF. Evaluation of topical gel bases formulated with various essential oils for antibacterial activity against methicillin-resistant staphylococcus aureus. Trop J Pharm Res 2013;12:877-84.

25. Lakshmana PS, Shirwaikar A, Shirwaikar A, Kumar A. Evaluation of rosin as a cream base for topical ketoconazole preparation. Pharm Res 2009;8:89-92.

26. Sareen R, Bhardwaj V, Mehta V, Sharma A. Topical gel incorporated with non-ionic surfactant based solid lipid microspheres of ketoprofen: physicochemical analysis and anti-inflammatory evaluation. Int J Pharm Pharm Sci 2016; 7:200-6.

27. Yadav V, Jadhav P, Dombe S, Bodhe A, Salunkhe P. Formulation and evaluation of microsponge gel for topical delivery of an antifungal drug. Int J Appl Pharm 2017;9:30-7. 